\title{
Operational Monitoring of the European Alps Using NOAA-AVHRR Imagery for Analysis of the Multi-Year Vegetation Index (NDVI)
}

\author{
Stefan Wunderle, Nando Foppa, David Oesch, Adrian \\ Hauser, Berne
}

\section{Introduction}

The European Alps are one of the most important obstacles for the atmospheric circulation in Europe with a mean height of $1.500 \mathrm{~m}$ covering an area of $240.000 \mathrm{~km}^{2}$ with a length of $1000 \mathrm{~km}$ and between 130 and $250 \mathrm{~km}$ wide. The orientation of the southern and central part is roughly southwest to northeast while the eastern part of the Alps runs from east to west. Many mountains exceed $4000 \mathrm{~m}$. The mountain range is the main divide between the temperate latitudes to the north and the Mediterranean to the south. It modifies the higher circulation pattern, contributing toward the complex structure of the wind, precipitation and temperature within this area. To complicate matters, almost every valley has its own climatic characteristic.

In recent years, some authors have stressed the importance of the Alps as an indicator of climate change (Beniston et al. 1997; Rebetez \& Beniston 1998; WANNER et al.1999; WANNER et al.1997). They assumed that changes in temperature as well as in precipitation will be more clearly observed in the Alps than in other regions in Europe because the changes would influence the amount and type of vegetation. In a warmer climate with sufficient precipitation the vegetation would extend into the upper regions of the Alps. To date, only small areas have been investigated by means of ground truth, verifying changes in the composition of the vegetation during the last 75 years (Keller et al. 2000).

One promising way to check whether the vegetation has changed is to analyze a time series of remote sensing data covering the whole Alpine area. It should be pointed out that the first useable satellite data of NOAA-AVHRR for our investigations stems from 1980. Therefore, we had only 20 years of satellite data available for our analysis. One widely accepted measure of vegetation in remote sensing studies is to calculate the Normalized Difference Vegetation Index (NDVI) using channels 1 and 2 of the NOAA-AVHHR sensor (Cihlar et al. 1991; ZHou et al. 2001). Unfortunately, the signal/noise ratio between changes in vegetation and the noise (uncertainty in calibration, errors in geocoding, different illumination and view angles due to drift of equator crossing time, etc.) is very small. Therefore, a data processing chain developed for mountainous terrain had to be used to improve the signal/noise ratio.

\section{Data}

The area of our investigation covers the whole European Alps. The subset borders of the received NOAA-AVHRR swath were set at 25 degrees East and the 0-Meridian. The range from North to South was 10 degrees, i.e. from 50 degrees North to 40 degrees North. This frame covers an area of approximately $890.000 \mathrm{~km}^{2}$ (see Figure 1).

We processed 846 AVHRR images from the years 1995 to 1998 and calculated the NDVI of every cloud free pixel. We presumed that the NDVI values would only change slightly in the course of the years. Thus, only the central part of the Alps was selected to avoid a domination of areas abundantly covered by vegetation, like the Po valley or the Swiss Midlands. The border of the Alpine region was defined after BäTZING et al. (1993). The negative effects of other influences, such as those in the atmosphere, the drift in sensor sensitivity and change of sun-target-sensor geometry were further reduced by analyzing only the maximum NDVI value of a 10-day interval. In addition, this technique reduces the number of overcast pixels in comparison to single imagery. This procedure and the gain on data quality are described in great detail in CIHLAR et al. 1997, EKLUNDH 1999 and KaUfmann et al. 2000. A minimum threshold of 0.08 and a maximum of 0.7 of NDVI were defined in order to eliminate pixels affected by cloud shadow or shaded by high mountains. Only values in-between these two thresholds were kept for the calculation of maximum NDVI of three 10-day composites per month. Further, the maximum NDVI of every pixel and every month was computed. We calculated the mean maximum NDVI for the whole area of the Alps as well as for six altitude levels, i.e. below $500 \mathrm{~m}, 501-1000 \mathrm{~m}, 1001-1500 \mathrm{~m}$, 1501-2000 m, 2001-2500 $\mathrm{m}$ and above $2501 \mathrm{~m}$.

\section{Methods}

Since 1981, the Remote Sensing Research Group of the Department of Geography receives and archives NOAA-AVHRR data covering the total area of the Alps. One of our main objectives is the investigation of environmental parameters of the last 20 years for 


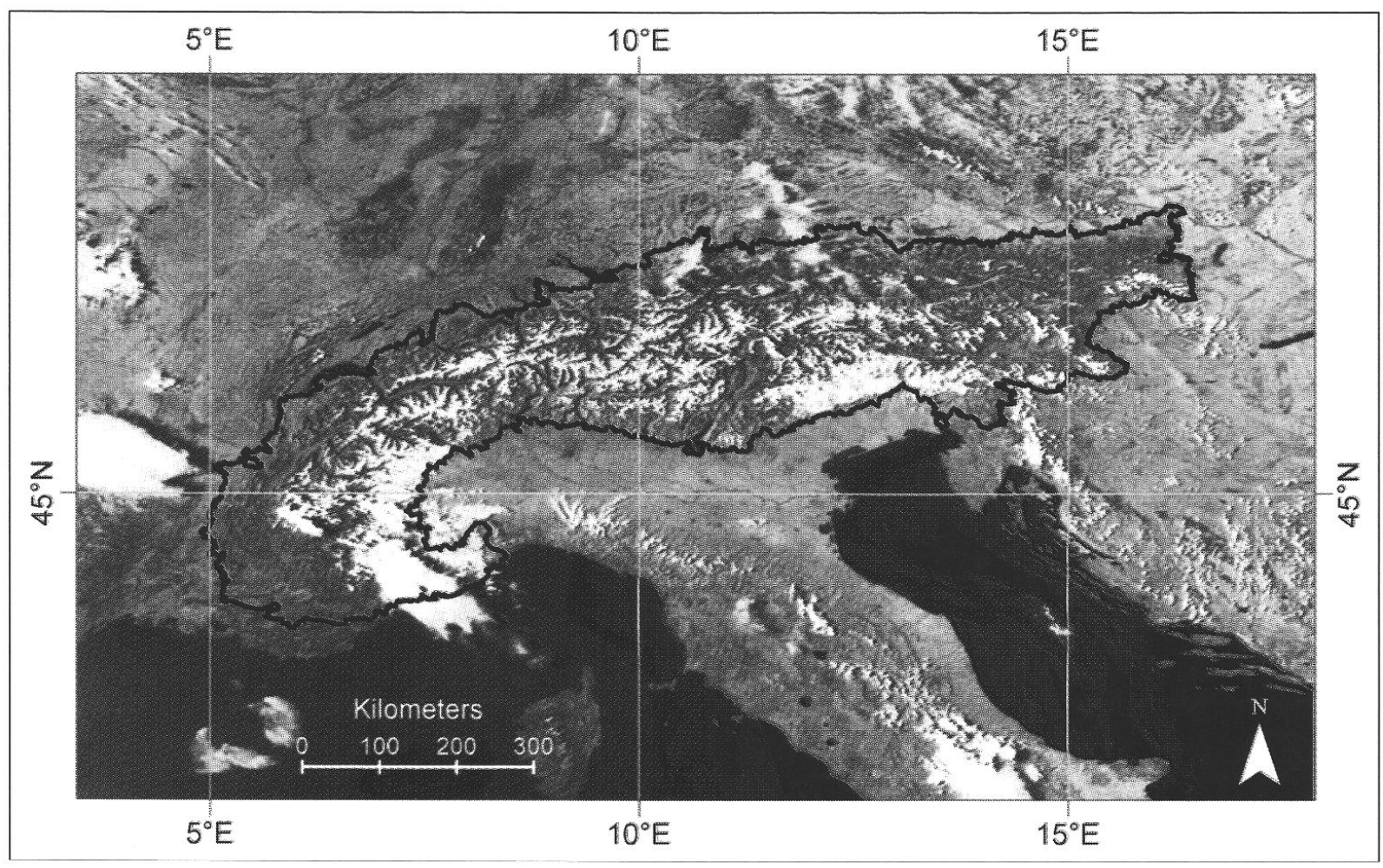

Fig. 1: The area of our investigations and the routinely processed frame of NOAA-AVHRR cover the whole European Alps. The images from the NOAA-12 were received on June 26, 2001 (15.42 UTC). The borderline of the Alps is defined after BäTZING et al. (1993) and shows the area of the NDVI analysis.

Das Untersuchungsgebiet sowie der regelmässig verarbeitete Ausschnitt der NOAA-AVHRR Szene deckt den gesamten Alpenraum. Die Aufnahme von NOAA-12 wurde am 26. Juni 2001 um 15.42 UTC gemacht. Die Grenze der Alpen (nach BäTzING et al. 1993) umschliesst das Gebiet für die Analyse des Vegetationsindexes NDVI.

Le périmètre de nos investigations et le découpage du traitement automatisé de la couverture NOAA-AVHRR couvrent l'ensemble de l'arc alpin. Les images de NOAA-12 ont été prises le 26 juin 2001 (15.42 UTC). Les limites des Alpes selon BäTzING et al. (1993) définissent le périmètre de l'analyse de l'index de végétation NDVI.

Source: Remote Sensing Research Group, University of Berne (2002)

the whole Alpine area. The aim is to make at least one data set per day available for our studies on changes of land surface parameters. Since August 2001, we are in an operational status to receive all available NOAA passes per day with a reliability of almost $100 \%$. The amount of archived data exceeds the number of 16.000 NOAA-AVHRR images and increases by $5-8$ new data takes every 24 hours from NOAA-12, NOAA-14, NOAA-15, NOAA-16 and NOAA-17, respectively. The great advantage of NOAA-AVHRR is that it has been operational without interruption for more than 20 years using the same sensor configuration. The only change was the addition of a further channel from NOAA-15. Additionally, one NOAA-AVHRR sensor covers the same region on the earth with a swath of $2700 \mathrm{~km}$ twice a day - thus offering the best conditions for an operational monitoring system of the European Alps.

The topography of the Alps with its high mountains and steep valleys, as well as the wide-angle characteristic of the AVHRR sensor, is a challenge for remote sensing. These conditions made it necessary to develop special modules to process NOAA-AVHRR data in an operational manner that does not require human interaction. The following modules are part of our processing chain (Figure 2): calibration of the data, which includes a satellite intercalibration of NOAA-9 to NOAA-16; automatic geocoding of the data in subpixel accuracy using feature detection; correction of the ortho-shift; terrain normalization; atmospheric correction based on SMAC (Simplified Method of Atmospheric Correction); correction of the non-Lambertian behavior of the surface and cloud masking using the Cloud and Surface Parameter Retrieval (CASPR) of the University of Wisconsin-Madison (KEY 2001).

Based on the orbit, the calculated view angle and the altitude of the mountains derived from GTOPO30, 


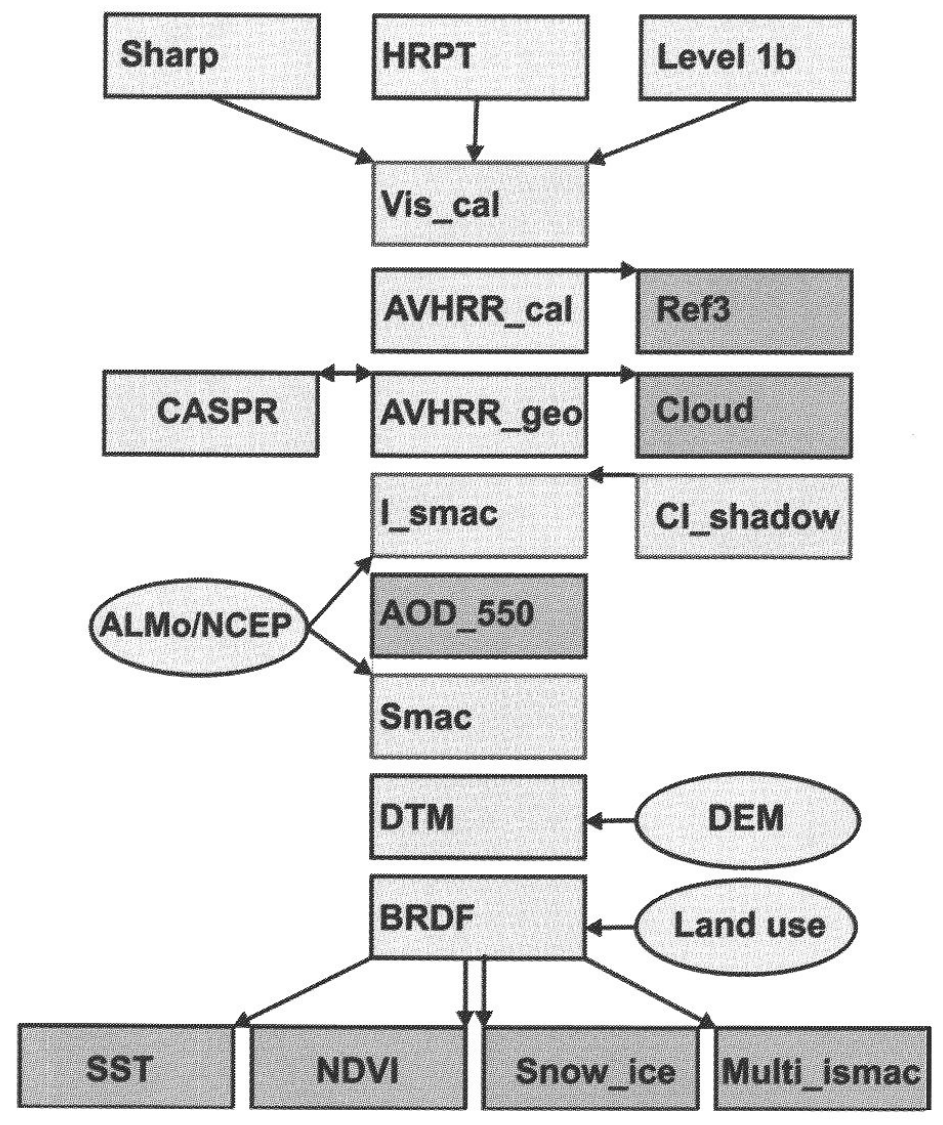

Fig. 2: NOAA-AVHRR processing chain designed for Alpine studies with the following modules: calibration (Vis_cal,AVHRR_CAL), geocoding (AVHRR_GEO), cloud masking (CASPR), aerosol distribution (I_smac), atmospheric correction (Smac), orthorectification (DTM) and BRDF correction (BRDF). The results are cloud cover (cloud), sea surface temperature (SST), Normalized Difference Vegetation Index (NDVI), snow classification (SNOW/ICE) and the calculation of an additional aerosol product (multi_ismac).

NOAA-AVHRR Prozessierungskette, entwickelt für Gebirgsstudien mit den Modulen Kalibration (Vis_cal, AVHRR_CAL), Geokodierung (AVHRR_GEO), Wolkenmaskierung (CASPR), Aerosolverteilung (I_smac), Atmosphärenkorrektur (smac), Orthorektifizierung (DTM) und BRDF Korrektur (BRDF). Als Ergebnis werden die Wolkenbedeckung (cloud), Temperatur der Wasseroberflächen (SST), Vegetationsindex (NDVI), Schneekarten (SNOW/ICE) und die Berechnung eines weiteren Aerosolprodukts (multi_ismac) aufgeführt.

Chaîne de traitement NOAA-AVHRR, développée pour des études en montagne avec les modules de calibrage (Vis_cal, AVHRR_CAL), de géocodage (AVHRR_GEO), de masquage des nuages (CASPR), de distribution des aérosols (I_smac), de correction des aérosols (smac) d'ortho-rectification (DTM) et correction de BRDF (BRDF). Les résultats comportent la couverture nuageuse (cloud), la température de la surface marine (SST), l'indice de végétation normalisé (NDVI), la classification de la neige (SNOW/ICE) et le calcul d'un produit complémentaire des aérosols (multi_ismac).

the ortho-shift is calculated for every pixel and afterwards corrected. The result is a NOAA-AVHRR image in parallel projection similar to topographic maps.

Where land surface parameters of mountainous regions are the main objective of the study, close attention has to be paid to the calculated reflectance, as it is strongly influenced by the local incidence angle of the illumination, by the view angle of the sensor and by the angle of the slopes.
The calculated reflectance of the normalized imagery is based on the assumption of a Lambertian surface. Therefore, a module was added to correct the bi-directional reflectance distribution (BRD). The BRD correction was done for the surface classes forest, barren, cropland and grass using the function published by Wu et al. (1995). The BRD corrected reflectance was normalized to a nadir view with a solar zenith of $45^{\circ}$. The surface classes of the $1 \mathrm{~km}$ Global Land Cover Map of the University of Maryland were used (HANSEn et al. 2000). The original 13 classes were 
combined to create 5 classes: forest, barren, cropland, grass and water.

One challenging aspect of long term monitoring is the correction of the atmospheric influence on the reflectance of the surface. Besides ozone, the main atmospheric contents relevant for the attenuation and scattering of the radiation are water vapor and aerosols. The atmospheric correction was done using the Simplified Method of Atmospheric Correction (SMAC) based on the 5S model (Rahman \& Dedieu 1994). The SMAC requires the atmospheric parameters water vapor, ozone, aerosol and pressure. These are however often not available in a suitable spatial resolution. As there are no values available for aerosol distribution in the Alps, we used a constant value $(\mathrm{AOD}=0.1)$. We thus used the water vapor, ozone content and pressure values distributed by the National Centers for Environmental Prediction (NCEP) with a spatial resolution of $2.5 \times 2.5$ degrees for the archived data.

The thus preprocessed data served as a basis for deriving land surface parameters, such as the normalized difference vegetation index (NDVI) from NOAAAVHRR data. NDVI is a measure of the greenness of the surface and is calculated by using channel 1 (VIS) and channel 2 (NIR) of the AVHRR sensor.

NDVI $=(\operatorname{ch} 2-\operatorname{ch} 1) /(\operatorname{ch} 2+\operatorname{ch} 1)$

Equation 1

The actual difference between the reflected sunlight from the red part of the spectrum (channel 1), which is that part which the vegetation absorbs for photosynthesis, and the reflected energy in the near infrared (channel 2), that part which the vegetation cannot use for photosynthesis, gives a qualitative measure indicating whether photosynthesis is taking place or not. NDVI values range from -1.0 to +1.0 and are unitless. Values greater than 0.1 generally denote increasing degrees in the greenness and intensity of vegetation. Values between 0 and 0.1 are commonly characteristic of rocks and bare soil, and values less than 0 sometimes indicate clouds, water and snow. Vegetated surfaces typically have NDVI values ranging from 0.1 in deserts up to 0.8 in dense tropical rain forest.

\section{Results}

Generally, the temporal aspect of NDVI data defines the shape of the graphs. The inter-annual cycle with low winter NDVI values and a maximum during summer was clearly apparent. After closer inspection, some features stood out and are worth mentioning. Figure 3 shows the cycle of NDVI for the whole Alps, as well as for the different altitudinal levels from January 1995 until December 1998. Thus A depicts the values at alti- tudes below $500 \mathrm{~m}, \mathrm{~B}$ at $501-1000 \mathrm{~m}, \mathrm{C}$ at $1001-1500 \mathrm{~m}$, $\mathrm{D}$ at $1501-2000 \mathrm{~m}, \mathrm{E}$ at $2001-2500 \mathrm{~m}$ and $\mathrm{F}$ at altitudes above $2500 \mathrm{~m}$.

Most of the maxima and minima values during the years of observation (cf. Figure $3 \mathrm{~A}$ ) are close together. The minimum of winter $97 / 98$ is here an exception with a difference of 0.1 between the spatial mean of the Alps and the altitudinal level $<500 \mathrm{~m}$. Therefore, during winter of $97 / 98$ the area below $500 \mathrm{~m}$ was much greener than during other years. As described in Chapter 2, only those pixels were used that had NDVI values between 0.08 and 0.7 . Thus, pixels completely covered by snow (NDVI <0.05) were excluded from the analysis. Mixed pixels with partial snow cover were taken into consideration. To explain the exceptional behavior of the above mentioned winter, it would be necessary to use additional information, like snow maps. In the future, we will use snow maps derived from NOAA-AVHRR imagery to validate the NDVI. Until now, we have made use of air temperatures at different stations in Switzerland to initially clarify whether snow might cover the area or not. The monthly mean temperature of Zurich $(556 \mathrm{~m}$ ) during the winter of $1997 / 98$ was marginally above the $0^{\circ} \mathrm{C}$ line. Hence, snow cover could not completely cover the area below $500 \mathrm{~m}$, which resulted in a visibility of the vegetation for remote sensing sensors. This finding explains the high NDVI values during the winter of $97 / 98$, in comparison to the years 95/96 and 96/97.

The same behavior can be seen for the altitudinal level 501-1000 m (Figure 3B). The maxima and minima of the years are close together but again the winter of 97/98 stands out. Therefore, at this height the snow cover was also not persistent. A deviant behavior can be observed for the altitudinal level 1001-1500 m (Figure 3C). The difference between the overall mean of NDVI of the Alps and this level disappeared during the wintertime. We presume it was cold enough for snow cover, resulting in a decrease of the NDVI value of approximately 0.1 . But there could be other reasons. The strong increase of winter NDVI in the course of the years 1995 to 1998 is for the first time clearly visible because the NDVI of the overall mean of the Alps and the NDVI values of the altitudinal level $1001-1500 \mathrm{~m}$ are congruent most of the time. Thus, the increase of winter NDVI could be due to changes in the snow cover. This result was confirmed using the NDVI values of the level 1501-2000 m (Figure 3D) where a slight increase of the winter NDVI values was observed. Above this elevation it was cold enough for snow to accumulate, resulting in low NDVI values (cf. Figure $3 \mathrm{E}$ and $\mathrm{F}$ ).

The question is whether the described findings are significant or not. To verify the explanation we calculated 


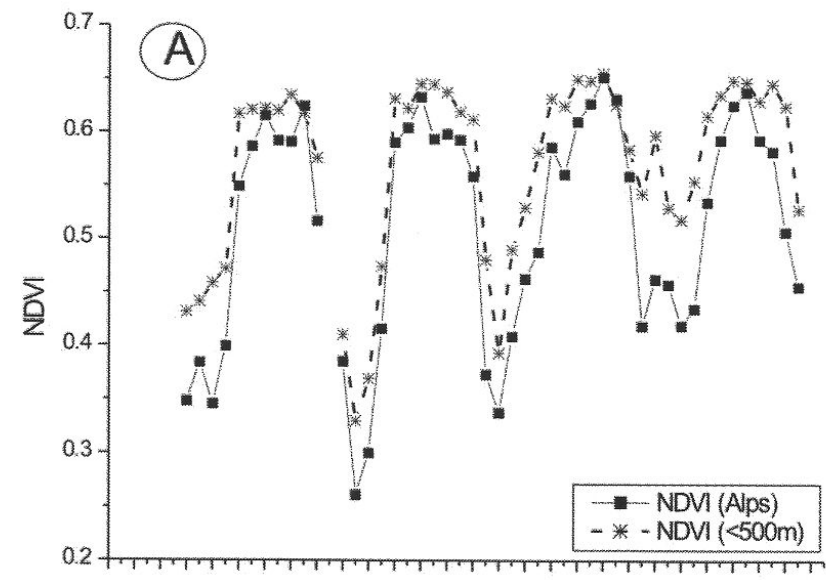

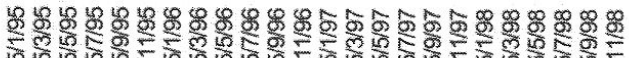

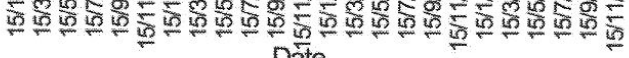
Date

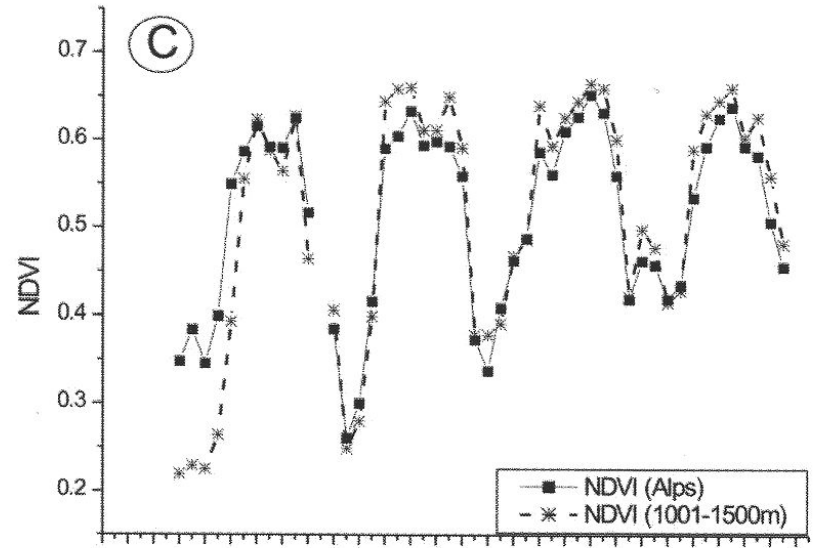

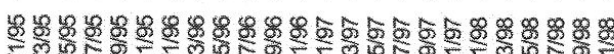

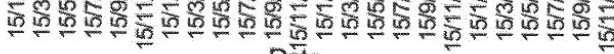
Date

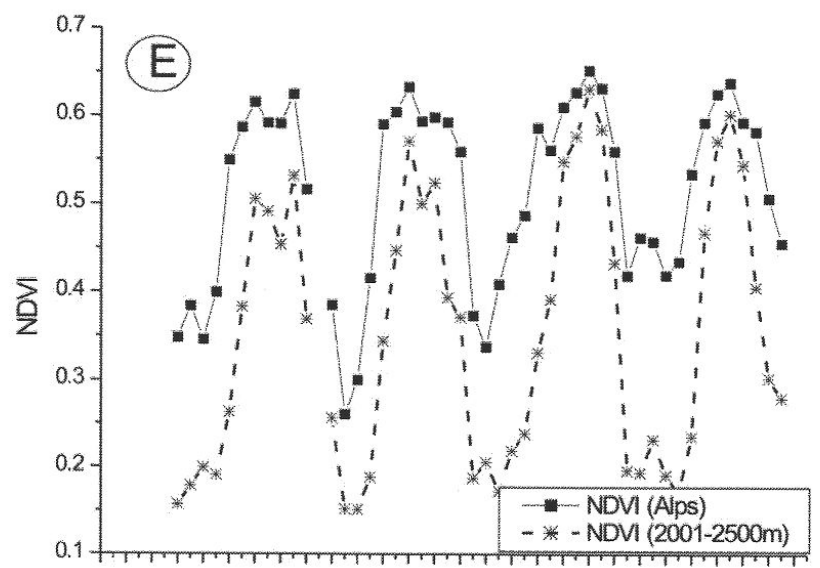

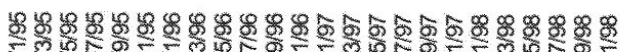

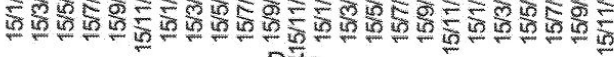

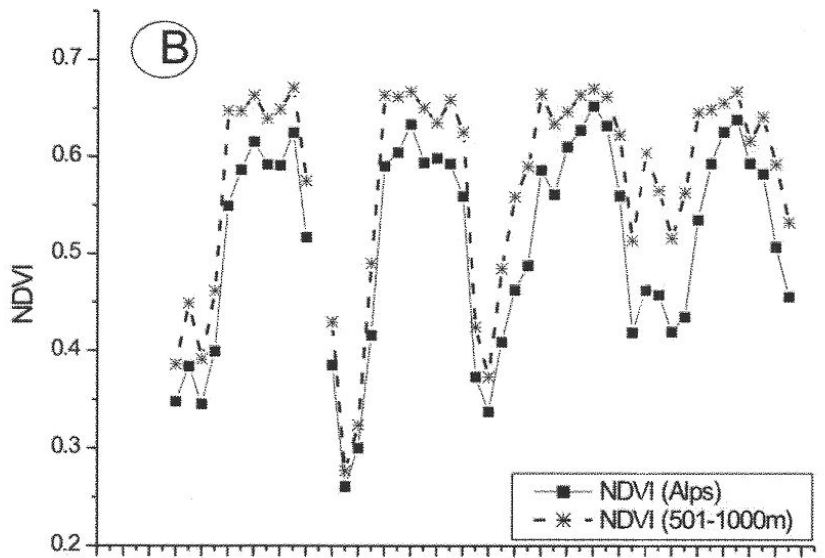

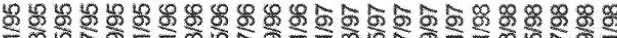

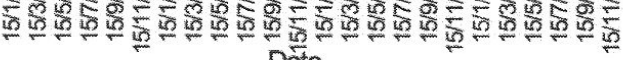
Dáte

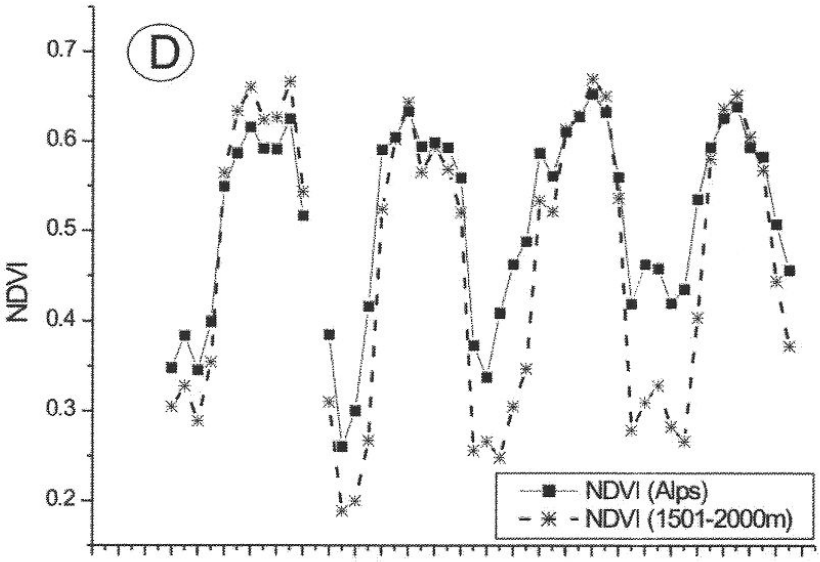

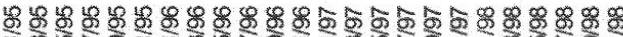

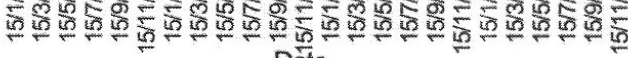
Dăte

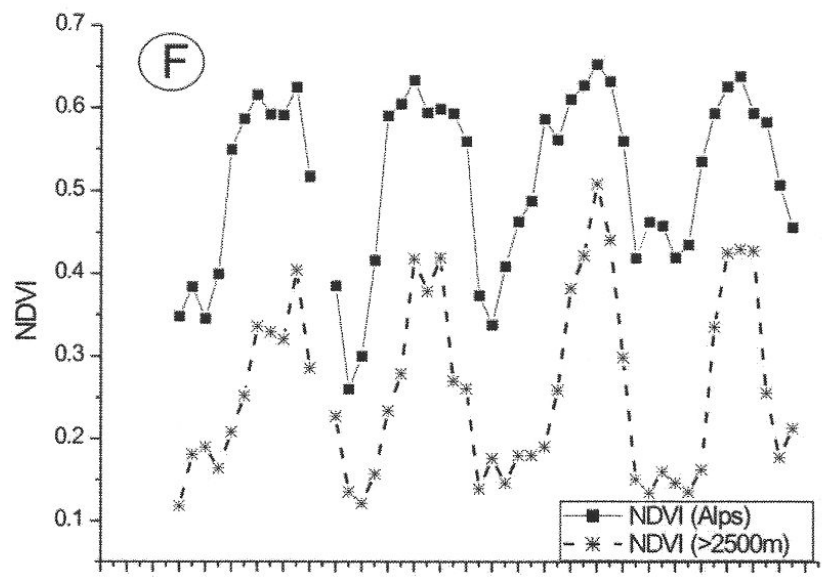

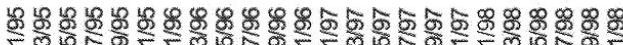

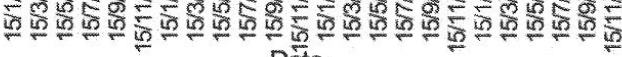
Date

Fig. 3: Annual variation of NDVI for the Alps, as well as for the altitudes $<500 \mathrm{~m}$ (A), $501-1000 \mathrm{~m}$ (B), 1001-1500 m (C), 1501-2000 m (D), 2001-2500 m (E) and >2501 m, respectively. The data are plotted for the years 1995 to 1998. Jährliche Schwankung des NDVI für die Gesamtalpen und für die Höhenstufen $<500 m(A), 501-1000 m(B)$, 1001-1500 m (C), 1501-2000 m (D), 2001-2500 m (E) und >2501 m. Die Daten zeigen den Zeitraum 1995 bis 1998. Variation annuelle du NDVI pour les Alpes et pour les étages altitudinaux $<500 \mathrm{~m}(A), 501-1000 \mathrm{~m}(B), 1001-1500$ $m(C), 1501-2000 m(D), 2001-2500 m(E)$ et >2501 m. Les données concernent les années de 1995 à 1998. 

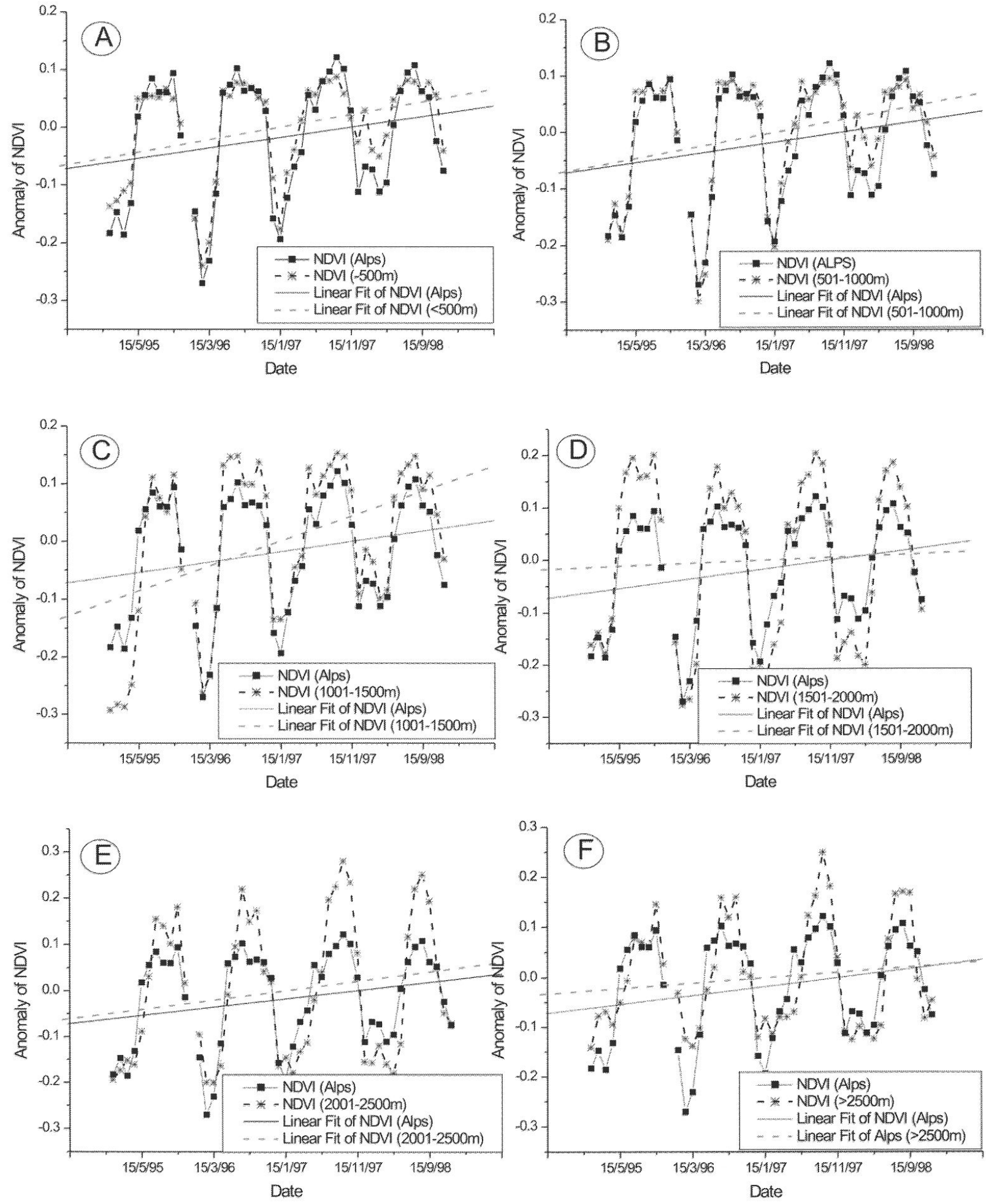

Fig. 4: Anomaly of NDVI and the linear fit for the Alps as well as for the altitudes $<500 \mathrm{~m}$ (A), 501-1000 m (B), 1001-1500 m (C), 1501-2000 m (D), 2001-2500 m (E) and >2501 m, respectively. The data are plotted for the years 1995 to 1998.

Abweichung des NDVI vom vier-jährigen Mittel mit Regressionsgeraden für die Gesamtalpen und für die Höhenstufen <500 m (A), 501-1000m (B), 1001-1500 m (C), 1501-2000m (D), 2001-2500m (E) und >2501m. Die Daten zeigen den Zeitraum 1995 bis 1998.

Anomalies du NDVI et écart de la moyenne sur quatre ans, avec la droite de régression pour les Alpes et les étages altitudinaux $<500 m(A), 501-1000 m(B), 1001-1500 m(C), 1501-2000 m(D), 2001-2500 m(E)$ et $>2501 \mathrm{~m}$. Les données concernent les années de 1995 à 1998. 

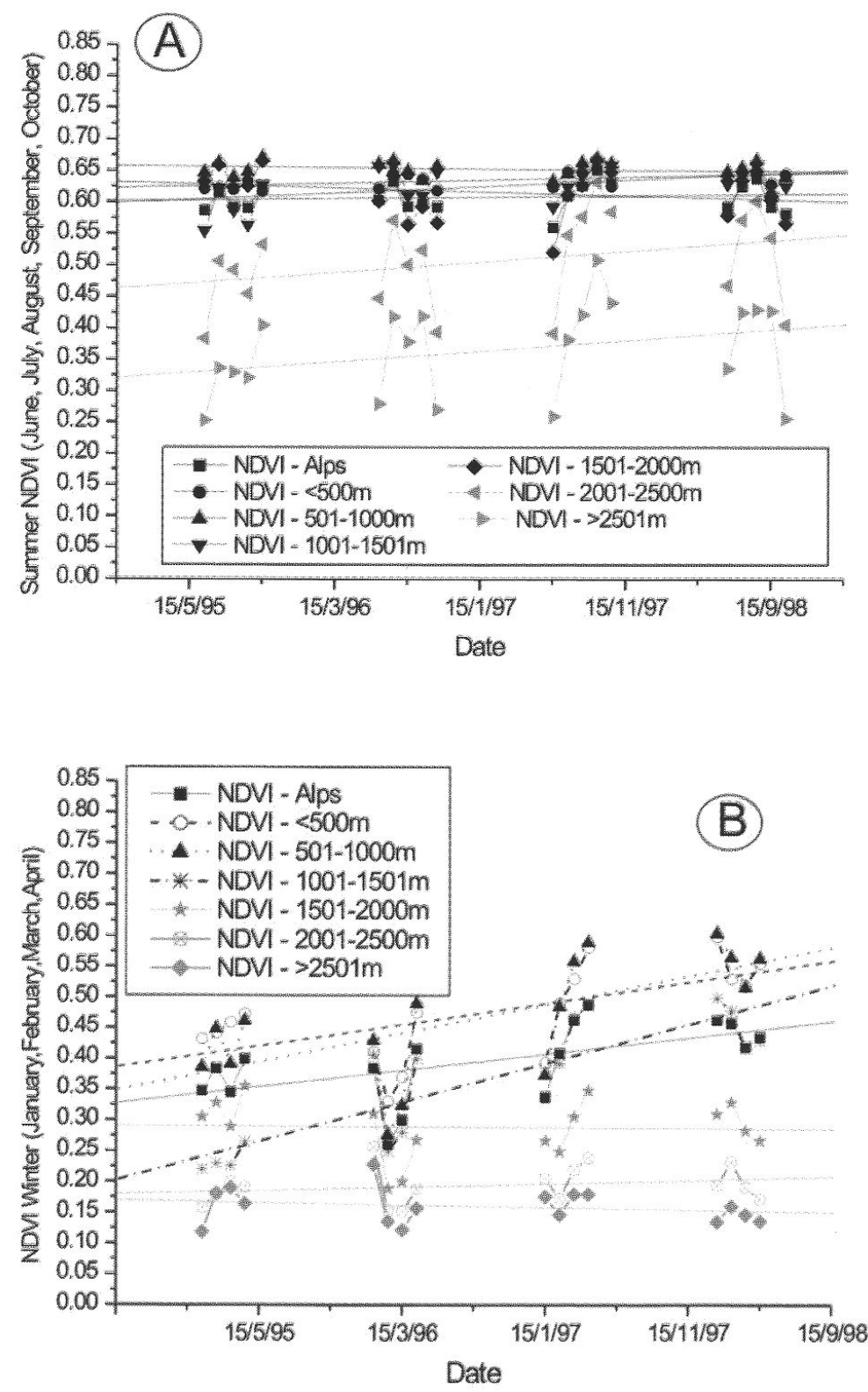

Fig. 5: Normalized Difference Vegetation Index for summer (June, July, August, September and October) (A) and winter (January, February, March and April) (B) in the Alps. The winter-NDVI values of the elevations $<500$ $\mathrm{m}, 501-1000 \mathrm{~m}$ and 1001-1500 $\mathrm{m}$ show a clear increase due to a decrease of the snow cover (B).

NDVI der Sommermonate (Juni, Juli, August, September und Oktober) (A) und der Wintermonate (Januar, Februar, März und April) (B) für die Alpen. Die NDVI-Werte des Winters der Höhenstufen $<500$ m, 501-1000 m und 1001-1500 m zeigen einen eindeutigen Anstieg durch die Abnahme der Schneebedeckung (B).

Index normalisé de la végétation dans les Alpes en été (juin, juillet, août, septembre et octobre) $(A)$ et en hiver (janvier, février, mars et avril) (B). L'indice hivernal des étages altitudinaux $<500 \mathrm{~m}, 501-1000 \mathrm{~m}$ et 1001-1500 m confirme une augmentation nette due à une diminution de la couverture neigeuse $(B)$.

the difference between the NDVI values and the specific 4-year mean of every altitudinal level. The resulting anomaly of NDVI with a linear fit is shown in figure $4 \mathrm{~A}-\mathrm{F}$.

The only significant trend could be found for the altitudinal level 1001-1500 $\mathrm{m}$ - the level in the Alps with a high snow line dynamic (Figure 4C). The linear fits of the inter-annual cycle of NDVI for the other altitudinal levels show a tendency of an increase but the trend is not significant. Thus it was interesting to analyze the behavior of the winter and summer NDVI values of the different levels separately. The summer was defined using the highest NDVI values which occur 
in June, July, August, September and, unexpectedly, in October. The higher the altitudinal level the later the occurrence of the NDVI maximum. Hence, the month October has to be included.

In the chart of NDVI summer values (Figure 5A) there is no trend indication of NDVI for the altitudinal levels $<500 \mathrm{~m}, 501-1000 \mathrm{~m}, 1001-1500 \mathrm{~m}$ or $1501-2000 \mathrm{~m}$. At 2001-2500 m a.s.l. and above $2501 \mathrm{~m}$ a.s.l. a slight increase could be detected, but this is without significance. The calculated linear fit highlights this tendency. Whether this deviation has to do with smaller areas of snow cover or greener vegetation can only be clarified by a longer time series. In contrast, the NDVI values of winter show a different behavior (Figure 5B). In the highest elevation no trend is detectable but there is a noticeable increase of winter NDVI for the elevations $<500 \mathrm{~m}, 501-1000 \mathrm{~m}$ and 1001-1500 m. Especially the linear fit of the NDVI values of the altitudinal level 1001-1500 $\mathrm{m}$ indicates a significant increase. The NDVI in January 1995 is 0.2 , whereas the NDVI of January 1998 exceeds 0.4 .

Assuming the difference is due to changes in the snow cover, the albedo of huge areas in the Alps decreased significantly. The mean albedo of snow cover, depending on the age and the pollution, is $0.8-0.6$. The albedo of a vegetation canopy is approximately 0.2. Taking this into account, the absorption of the short wave radiation would thus be much higher, thereby influencing the energy fluxes to a great extent. A possible positive feedback in the energy fluxes would lead towards a further decrease of the snow covered areas at $1000-1500 \mathrm{~m}$ a.s.l. However, our analysis is only based on a time series of four years. It is therefore not possible to define a general trend for the Alps or for specific altitudinal levels on the results available. Further years have to be processed and analyzed to verify these findings.

\section{Discussion}

The preprocessing of almost 900 NOAA-AVHRR images was fully automated without any human interaction. We presume that the remaining error in the NDVI data is minor due to the usage of only the maximum NDVI values in distinct time frames of 10 days and 1 month, respectively. Shabanov et al. (2001) pointed out that the maximum NDVI is minimally sensitive to sun angle changes and this sensitivity decreases as leaf area increases. One weak point of the processing chain is the atmospheric correction because it is based on a coarse spatial resolution of 2.5 x 2.5 degrees for the variables water vapor, ozone and pressure. In addition, a standard value for the aerosol optical depth for the whole area and period was used.
This may have caused an error in the magnitude of the NDVI values because the aerosol interacts differently on the visible and near infrared spectrum. Hence, the absolute value of NDVI may differ but the behavior in general and the shape of the graphs will remain.

The analysis of NDVI focused on the Alpine area defined by BätzING et al. (1993), as well as on the altitudinal levels $<500 \mathrm{~m}, 501-1000 \mathrm{~m}, 1001-1500 \mathrm{~m}$, $1501-2000 \mathrm{~m}, 2001-2500 \mathrm{~m}$ and $>2500 \mathrm{~m}$. The values of NDVI of the different areas are distinct and show an interesting behavior. The only significant trend of NDVI could be detected at the 1001-1500 m level, whereas at the other levels there is an indication that trends are increasing. Therefore, we presume that the selection of more altitudinal levels will not show better results. In addition, the database of available cloud free pixels would be too small to calculate the NDVI for every location and time frame.

Snow maps derived from NOAA-AVHRR will be included in further research to explain the behavior of NDVI during the wintertime. The module snow/ice of our processing chain will be used to simultaneously process snow maps and NDVI values. This will help to determine whether the increasing NDVI values during wintertime are due to smaller snow covered areas or due to greener vegetation. In addition, the influence of precipitation on the NDVI maximum should be examined. At a global scale, a relationship between temperature, precipitation and NDVI could be found by SCHULtz \& HALPERT (1993). They showed that the vegetation in cold regions is limited by temperature, and by both precipitation and temperature in temperate regions. Thus, it would be of interest to examine the relationship between precipitation, temperature and NDVI in the Alps using a longer time series.

\section{Acknowledgement}

We wish to thank MeteoSchweiz for the air temperature of the on-line databank. The research was partly supported by a grant from the Swiss National Science Foundation (21-58829.99).

\section{Literature}

BätzıNG, W. et al. (1993): Der sozio-ökonomische Strukturwandel des Alpenraumes im 20. Jahrhundert. Eine Analyse von «Entwicklungstypen» auf GemeindeEbene im Kontext der europäischen Tertiarisierung. Geographica Bernensia (P26).

Beniston, M., Diaz, H.F. \& R.S. Bradley (1997): Climatic Change at High Elevation Sites: An Overview.In: Climatic Change 36, 3/4: 233-251.

Cinlar, J., Ly, H., Li, Z., Chen, J., Pokrant, H. \& F. HUANG (1997): Multitemporal, multichannel AVHRR 
data sets for land biosphere studies - artifacts and corrections. - In: Remote Sensing of Environment 60: 35-57.

Cihlar, J., St.-Lauren, L. \& J.A. Dyer (1991): Relation between the normalized difference vegetation index and ecological variables. - In: Remote Sensing of Environment 35: 279-298.

EKLUNDH, L.R. (1999): Noise estimation in NOAA AVHRR maximum-value composite NDVI images. In: International Journal of Remote Sensing 16/15: 2955-2962.

Hansen, M.C., Defries, R.S., Townshend, J.R.G. \& R. SoHLberg (2000): Global land cover classification at $1 \mathrm{~km}$ spatial resolution using a classification tree approach. - In: International Journal of Remote Sensing 21/6,7: 1331-1364.

Kaufmann, R.K., Zhou, L., Knyazikhin, Y., Shabanov, N.V., Myneni, R.B. \& C.J. Tucker (2000): Effect of Orbital Drift and Sensor Changes on the Time Series of AVHRR Vegetation Index Data. - In: IEEE Transactions on Geoscience and Remote Sensing 38,6: 2584-2597.

Keller, F., Kienast, F. \& M. Beniston (2000): Evidence of response of vegetation to environmental change on high-elevation sites in the Swiss Alps. - In: Regional Environmental Change 1, 2: 70-77.

KEY, J.R. (2001): The Cloud and Surface Parameter Retrieval (CASPR) System for Polar AVHRR - User's Guide, Version 3.2. - Cooperative Institute for Meteorological Satellite Studies, University of Wisconsin, Madison Wisc., 61 pp.

Rahman, H. \& G. Dedieu (1994): SMAC: a simplified method for the atmospheric correction of satellite measurements in the solar spectrum. - In: International Journal of Remote Sensing 15, 1: 123-143.

Rebetez, M. \& M. Beniston (1998): Changes in temperature variablility in relation to shifts in mean temperature in the Swiss alps. The impacts of climate variability on forests. - In: BENISTON, M. \& J.L. INNES (Hrsg.): The impacts of climate variability on forests Lecture notes in earth science: 49-58. - XIV, Berlin: Springer-Verlag, $329 \mathrm{pp}$.

Shabanov, N. , Zhou, L., Knyazikhin, Y., Myneni, R.B. \& C.J.TUCKer (2001): Analysis of Interannual Changes in Northern Vegetation Activity Observed in AVHRR Data during 1981 to 1994. - In: IEEE Transactions on Geoscience and Remote Sensing 40, 1: 115-130.

Schultz, P.A. \& M.S. Halpert (1993): Global correlation of temperature, NDVI and precipitation. - In: Advances in Space Research 13, 5: 5277-5280.

Wanner, H., Rickli, R., SAlvisberg, E., Schmutz, C. \& M. Schuepp (1997): Global climate change and variability and its influence on Alpine climate-concepts and observations. - In: Theoretical and Applied Climatology 58, 3-4: 221-243.

Wanner, H., Holzhauser, H., Pfister, C. \& H. ZumbüHL (1999): Interannual to century scale climate variability in the European Alps. - In: Erdkunde 54: 62-69.

Wu, A., Li, Z. \& J. Cihlar (1995): Effects of land cover type and greenness on advanced very high resolution radiometer bidirectional reflectances: analysis and removal. - In: Journal of Geophysical Research 100, 5D: 9179-9192.

Zhou, L., Tucker, C.J., Kaufmann, R.K., Slayback, D., Shabanov, N.V. \& R.B. Myneni (2001): Variations in Northern Vegetation Activity Inferred from Satellite Data of Vegetation Index During 1981 to 1999. - In: Journal of Geophysical Research 106, D17: 20069-20083.

\section{Summary: Operational Monitoring of the European Alps Using NOAA-AVHRR Imagery for Analysis of the Multi-Year Vegetation Index NDVI}

It could be shown that the normalised difference vegetation index (NDVI) can be automatically processed for mountainous terrain characterised by steep slopes and high cloud coverage throughout the year. The quality of the data can be improved if the variables for the atmospheric correction (water vapor, ozone and pressure) are taken from a finer grid resolution and if the actual aerosol optical depth is used. However, even under these improved concitions, the magnitude of the NDVI would differ but the behavior and shape of the graphs in general would remain. The upward trend of the winter NDVI in the years 1995-1998 is significant for the altitudinal levels $1001-1500 \mathrm{~m}$ and $501-1000 \mathrm{~m}$. To be able to find out more about the snow covered areas at these heights, reference was made to the air temperatures of Zurich, Engelberg and Santis. Thus, we were able to show that the increase of NDVI at lower elevations during the wintertime was linked to decreasing snow covered areas. In elevations above $2000 \mathrm{~m}$, a slight increase in the summer NDVI could be detected but the linear trend is not significant. An explanation for this could not be given due to missing meta-data, such as the extent of the snow covered area. In conclusion, it may be said that there is a good correlation between the air temperature and the NDVI, but that the quality of the precipitation database does not allow for a correlation to be made between precipitation and the NDVI.

\section{Zusammenfassung: Automatische Überwachung der Europäischen Alpen mittels NOAA-AVHRR-Daten zur Analyse eines mehrjährigen Vegetationsindexes (NDVI)}

Es konnte gezeigt werden, dass es möglich ist, NOAAAVHRR Daten in gebirgigem Gebiet mit steilen Tälern und einer hohen Wolkenbedeckung vollständig automatisch zu prozessieren, um den NDVI abzuleiten. Die gute Qualität der Daten kann sicherlich verbessert werden durch eine Optimierung der Atmosphärenkorrektur. 
Die Verwendung von aktuellen Aerosol-Daten sowie der Wasserdampf-, Ozongehalt und Luftdruck in einer grösseren räumlichen Auflösung werden den maximalen NDVI verändern, aber nicht das generelle Verhalten des NDVI-Zyklus. Der Anstieg der NDVI-Werte in den Winterhalbjahren 1995-1998 für die Höhenstufen 501-1000 $\mathrm{m}$ und $1001-1500 \mathrm{~m}$ ist signifikant. Als ein indirektes Mass für die Schneebedeckung wurde die Lufttemperatur der Stationen Zürich, Engelberg und Säntis verwendet. Wir konnten belegen, dass der NDVIAnstieg durch eine geringere Schneebedeckung in diesen Höhenzonen verursacht wird. In Höhen über $2000 \mathrm{~m}$ konnte ein leichter Anstieg des sommerlichen NDVI belegt werden, der jedoch nicht signifikant ist. Eine Erklärung für diesen Anstieg konnte nicht gefunden werden, da keine Zusatzdaten, wie die Schneebedeckung zur Verfügung standen. Wir konnten zeigen, dass eine gute Übereinstimmung der Lufttemperatur mit dem NDVI besteht, aber die Datenqualität der verfügbaren Niederschlagswerte nicht ausreichend war, um eine Beziehung zwischen Niederschlag und NDVI zu finden.

\section{Résumé: Monitoring opérationnel de l'arc alpin fondé sur l'imagerie de NOAA-AVHRR en vue de l'analyse de l'index de la végétation multi-annuelle (NDVI)}

Même pour des régions montagneuses escarpées, à couverture nuageuse importante tout au long de l'année, l'indice de végétation normalisé NDVI (ou Indice de végétation par la différence normalisée IDNV) peut être obtenu de manière entièrement automatique à partir de données NOAA-AVHRR. La bonne qualité des données peut être encore améliorée par l'optimisation de la correction atmosphérique. L'application de données actuelles des aérosols ainsi que de la vapeur d'eau, de la teneur en ozone et de la pression atmosphérique avec une résolution spatiale supérieure, risque de modifier la valeur NDVI maximale, mais non le comportement du cycle NDVI. L'augmentation des valeurs NDVI durant les semestres d'hiver 1995-1998 pour les étages altitudinaux de 501 à $1000 \mathrm{~m}$, ainsi que de 1001 à $1500 \mathrm{~m}$ est significative. Les températures de l'air des stations de Zurich, Engelberg et du Säntis ont servi de référence pour la couverture neigeuse. Nous avons pu prouver que l'augmentation du NDVI a été provoquée par une diminution de la couverture neigeuse à ces altitudes. Pour les altitudes au-dessus de $2000 \mathrm{~m}$, une faible augmentation du NDVI estival a pu être établie, mais cette tendance linéaire n'est pas significative. Tant que des données supplémentaires - comme la couverture neigeuse - font défaut, une explication n'a pas pu être donnée. Nous avons pu confirmer qu'il existe une bonne corrélation entre les températures de l'air et le NDVI, mais la qualité des données pluviométriques disponibles n'est pas suffisante pour démontrer un rapport entre les précipitations et le NDVI.

\section{Teaching in Geography - pertinent questions}

- What influence does precipitation have on the summer values of the NDVI?

- The increasing vegetation index in winter is a result of the decreasing snow cover. What are other possible causes?

- Is the NDVI time series a suitable indicator for climatic change in the Alps?

- Which parameters needed special attention during the investigation of NDVI in the Alps?

- Special attention was paid to which elevations and where were significant differences registered?

- What is the influence of summer rainfall on NDVI values? The increasing vegetation index in winter is related to decreasing snow cover. Are other causes possible?

- What parameter need to be included in future investigations?

- Can NDVI time series document climate change in the Alps?

Dr. Stefan Wunderle, Dipl.-Geogr. Nando Foppa, Dipl.Geogr. David Oesch, Dipl.-Meteo. Adrian Hauser, Remote Sensing Research Group, Department of Geography, University of Berne, Hallerstrasse 12, CH-3012 Berne.

e-mail:

swun@giub.unibe.ch

foppa@giub.unibe.ch oesch@giub.unibe.ch

adrian@giub.unibe.ch

\section{Manuskripteingang/received/manuscrit entré le} 14.2.2003

Annahme zum Druck/accepted for publication/accepté pour l'impression: 5.6.2003 